\title{
Pemanfaatan Pelepah Sawit dan Kotoran Ayam Ras untuk Pembuatan Pupuk Bokashi pada Kelompok Wanita Tani Padang Baru Babatan, Seluma, Bengkulu
}

\section{The Utilization of Oil Palm Midrib-leaf and Chicken Manure for Making Bokashi Fertilizer in the Women's Farmers Group Padang Baru Babatan, Seluma, Bengkulu}

\author{
Nurlianti*, Prihanani
}

Program Studi Agroteknologi Universitas Prof. Dr. Hazairin SH, Jl. Jend. Sudirman No. 185 Bengkulu, Indonesia

\begin{tabular}{|c|c|}
\hline Info Artikel & ABSTRAK \\
\hline $\begin{array}{l}\text { Diterima 04 Maret } 2021 \\
\text { Ditelaah 24 Juni } 2021 \\
\text { Disetujui 28 Juni } 2021 \\
\text { Tersedia daring } 30 \text { Juni } 2021 \\
\text { *Penulis untuk korespondensi } \\
\text { nurlianti.pertiwi@gmail.com } \\
\end{array}$ & $\begin{array}{l}\text { Tujuan dari kegiatan pengabdian ini adalah untuk memanfaatkan limbah pertanian yaitu } \\
\text { pelepah sawit dan limbah peternakan ayam ras yang banyak dijumpai di Kelurahan } \\
\text { Babatan, Kecamatan Sukaraja, Kabupaten Seluma, Bengkulu. Selain itu, program ini } \\
\text { bertujuan utuk menambah pengetahuan tentang pembuatan pupuk bokashi dan } \\
\text { memberikan keterampilan dalam membuat pupuk bokashi dengan bahan baku yang ada } \\
\text { di sekitar masyarakat mitra. Metode yang dilakukan adalah penyuluhan, demonstrasi } \\
\text { plot, dan pendampingan. Hasil kegiatan berupa penambahan pendapatan keluarga } \\
\text { dengan usaha membuatan bokashi yang memanfaatkan bahan baku limbah disekitar }\end{array}$ \\
\hline $\begin{array}{l}\text { Kata Kunci: } \\
\text { Bokashi, } \\
\text { Limbah pertanian, }\end{array}$ & $\begin{array}{l}\text { kehidupan mitra. Produk kegiatan adalah bokashi berbahan dasar pelepah sawit dan } \\
\text { limbah ternak ayam ras yang siap untuk dipasarkan. Mitra telah mampu menjual } \\
\text { produknya dalam jumlah terbatas untuk memenuhi kebutuhan kelompok tani lain atau } \\
\text { masyarakat umum yang membutuhkan. }\end{array}$ \\
\hline
\end{tabular}

Penambahan pendapatan

Keywords:

Agricultural waste,

Additional income,

Bokashi

\section{ABSTRACT}

The purpose of the community service program is to utilize agricultural waste, namely oil palm midrib-leaf and chicken manure which are often found in this Babatan Village, Sukaraja Subdistrict, Seluma Regency, Bengkulu. In addition, this program was aimed to increase knowledge and skill to produce bokashi fertilizer with raw materials found around them. The methods used were lecture, demonstration plots, and mentoring. The results of the activity were the increasing of family income by making bokashi utilizing waste raw materials around their lives, namely bokashi made from palm fronds and broiler chicken waste that is ready to be sold. In limited quantities, they have been able to sell their products to meet the needs of other farmer groups or the general public in need.

ISSN 2685-0354 (Media Online). Diterbitkan oleh Universitas Prof. Dr. Hazairin, SH. Ini merupakan jurnal bebas akses di bawah lisensi Creative Commons Atribution 4.0 International (https://creativecommons.org/licenses/by/4.0

\section{PENDAHULUAN}

Kecamatan Sukaraja berada di Kabupaten Seluma, Provinsi Bengkulu. Kecamatan ini mencakup wilayah 21 desa dan kelurahan dengan Kelurahan Babatan sebagai ibu kota kecamatan. Kecamatan Sukaraja merupakan kecamatan di Kabupaten Seluma yang berbatasan dengan Kota Bengkulu. Kelurahan Babatan berjarak kurang lebih $58 \mathrm{~km}$ dari pusat kota Bengkulu (BPS Seluma, 2020).

Kelurahan Babatan merupakan lokasi peternakan ayam ras yang terbanyak di Kabupaten Seluma dengan populasi 866.082 jiwa (BPS Seluma, 2020). Produksi ayam ras dari Kecamatan Sukaraja memasok kebutuhan akan daging ayam bagi Kota Bengkulu karena letak geografisnya dekat dengan Kota Bengkulu. Kecamatan Sukaraja 
memiliki luas lahan 189,46 $\mathrm{km}^{2}$ yang cukup luas dengan jumlah penduduk yang masih sangat jarang dengan kerapatan 174 orang $\mathrm{km}^{-2}$ sehingga masih cukup potensial untuk menjadi lokasi peternakana ayam ras.

Jumlah penduduk Kabupaten Seluma 207.877 jiwa dan penduduk Kecamatan Sukaraja yang bekerja di bidang pertanian sebanyak 68.781 jiwa. Komoditi tanaman perkebunan yang paling luas di Kabupaten Seluma pada tahun 2020 adalah tanaman kelapa sawit dengan luas 31.598 ha. Luas areal perkebunana sawit di Kecamatan Sukaraja adalah 8.202 ha (BPS Seluma, 2020).

Pelepah sawit yang dipangkas sebelum pemanenan buah sawit dibiarkan menumpuk di sekitar galangan sehingga sanitasi kebun menjadi rendah. Tumpukan pelepah kering dalam waktu lama akan menjadi tempat hidupnya kumbang Oryctes rhinoceros yang dapat menyerang pucuk pelepah sawit. Kumbang ini juga menjadi agen pembawa jamur Genoderma yang berpotensi menjadi patogen busuk pangkal batang sawit (Firmansyah, 2010).

Peternakan rakyat menimbulkan bau yang tidak sedap serta pemandangan yang tidak menarik karena tumpukan kotoran ternak. Kualitas lingkungan menjadi rendah akibat polusi yang disebabkan oleh bau yang tidak sedap dalam waktu yang lama. Potensi limbah kotoran ayam ras per hari sangat besar. Selama ini limbah tersebut dikeluarkan dari peternakan dan dibawa ke daerah lain yang membutuhkan. Pemanfaatan kotoran ayam ras sebagai pupuk organik membutuhkan waktu yang lebih lama karena $\mathrm{C} / \mathrm{N}$ ratio umumnya diatas 30 sehingga perlu dilakukan pengomposan terlebih dahulu untuk menurunkan $\mathrm{C} / \mathrm{N}$ ratio. $\mathrm{C} / \mathrm{N}$ ratio diharapkan sama dengan tanah yaitu kecil dari 20 (Siboro et al. 2013).

Potensi limbah ternak ayam ras dan limbah kebun sawit berupa pelepah sawit cukup besar untuk dijadikan bahan dasar pembuatan pupuk bokashi. Kualitas pembuatan pupuk bokashi akan tergantung dari bahan-bahan dasar yang digunakan. Pembuatan pupuk oganik dari pelepah sawit yang dicampur dengan kotoran ayam akan dapat menyumbang hara bagi tanah dan tanaman. Syahfitri (2008) menyatakan bahwa kandungan hara limbah daun sawit adalah N 2,6- 2,9\%; P 0,16-0,19\%; K 1,1-1,3\%; Ca 0,5-0,7\%; Mg 0,3-0,45\%; S 0,25-0,40\%; Cl 0,5- 0,7\%; B 15-25 $\mu \mathrm{g}^{-1} ; \mathrm{Cu} 5-8 \mu \mathrm{g}^{-1}$ dan $\mathrm{Zn} 12-18 \mu \mathrm{g}^{-1}$. Kotoran ayam mempunyai kadar unsur hara dan bahan organik yang tinggi serta kadar air yang rendah. Kotoran ayam memiliki kandungan unsur hara N 1\%; P 0,80\%; K 0,40\%; dan kadar air 55\% (Gunawan \& Talib, 2014).

Kedua bahan dasar tersebut (pelepah sawit dan kotoran ayam ras) dapat dijadikan pupuk bokashi dengan menggunakan bantuan EM-4 sebagai dekomposer. Kelebihan pupuk bokashi adalah pembuatannya dalam waktu yang relatif singkat yaitu 7 hingga 14 hari, tidak terdapat bau busuk, tidak mengandung hama dan penyakit, tidak membahayakan pertumbuhan tanaman, dan proses pertumbuhan tanaman lebih cepat karena kandungan hara lebih tinggi (BPTP Kalimantan Tengah, 2015). Pupuk bokashi mengandung mikroorganisme tanah efektif sebagai dekomposer yang dapat mempercepat proses dekomposisi bahan organik dalam tanah, sehingga dapat meningkatkan ketersediaan unsur hara N, P dan K bagi tanaman (Kaya, 2013). Penggunaan pupuk bokashi dicampur pupuk NPK mendapatkan hasil bobot buah timun per hektar 3 kali lipat lebih banyak dibanding penggunaan pupuk kandang dicampur pupuk NPK. Mikroorganisme yang menguntungkan dan senyawa organik lainnya yang terdapat dalam pupuk bokashi dapat meningkatkan keanekaragaman serta aktivitas mikroba dalam tanah sehingga mampu meningkatkan unsur hara dan menunjang pertumbuhan tanaman (Fitriany \& Abidin, 2020).

Kelompok Wanita Tani (KWT) Padang Baru yang berlokasi di Kelurahan Babatan diketuai oleh ibu Rosita beranggotakan 10 orang yang bekerja sebagai ibu rumah tangga. Anggota KWT Padang baru memiliki pekerjaan sambilan membantu suami sebagai pekebun sawit, sebagi pegelola ternak dan sebagian lagi tidak memiliki pekerjaan selain sebagai ibu rumah tangga. Ibu-ibu yang tergabung dalam kelompok wanita tani (KWT) ini memiliki banyak waktu luang pada saat anak-anak sekolah dan para suami bekerja di kebun. Waktu luang dan tenaga kerja dari wanita kelompok tani ini berpotensi untuk dikembangkan dalam rangka melakukan program kegiatan ekonomi produktif yang bermanfaat bagi peningkatan ekonomi keluarga.

Tujuan dari program pengabdian adalah untuk memanfaatkan limbah pertanian dari usaha budidaya kelapa sawit dan limbah peternakan masyarakat yang banyak dijumpai di desa ini. Selain itu, program ini bertujuan untuk menambah pengetahuan tentang pembuatan pupuk bokashi dan memberikan keterampilan dalam membuat pupuk bokashi dengan bahan baku yang ada disekitar mereka. Pada akhirnya, mitra diharapkan memiliki usaha produktif yang dapat menambah pendapatan keluarga.

\section{METODE}

Pengabdian pada masyarakat telah dilaksanakan di Kelompok Wanita Tani (KWT) Padang Baru Kelurahan Babatan Kecamatan Sukaraja Kabupaten Seluma. KWT Padang Baru ini merupakan binaan Fakultas Pertanian 
Universitas Prof. Dr. Hazairin, SH Bengkulu (Unihaz). Kegiatan pengabdian dosen Prodi Agroteknologi Fakultas Pertanian Unihaz secara berkala dan berkelanjutan diadakan di lokasi ini. Kegiatan pengabdian ini dilaksanakan bulan Januari hingga bulan Juni 2018.

Metode yang dilakukan adalah penyuluhan, demplot, dan pendampingan. Penyuluhan dilaksanakan untuk membuka wawasan dan memberikan pemahaman materi pembuatan pupuk bokashi berbahan dasar pelepah sawit dan kotan ayam ras yang kesemuan bahan ada dan dimiliki oleh anggota kelompok KWT Padang Baru. Selanjutnya Tim Pengabdian Unihaz melaksanakan demplot teknik pembuatan pupuk bokashi pelepah sawit dan kotoran ayam ras yang bertujuan untuk memberi ketrampilan kepada anggota kelompok. Pendampingan adalah kegiatan pengabdian yang memberikan kesempatan kepada anggota kelompok untuk melaksanakan secara mandiri dan Tim Pengabdian Unihaz hanya menjadi mendukung dan mengevaluasi untuk kemudian meluruskan agar kegiatan pembuatan bokashi sesuai dengan teori yang telah diberikan.

Bahan yang digunakan adalah sekam padi, pelepah sawit, kotoran ayam ras, EM-4, dedak, molase. Alat yang digunakan adalah mesin coper pencacah pelepah sawit, terpal, rumah fermentasi, ember, gembor, cangkul. Semua alat dan bahan disediakan oleh Tim Pengabdian Unihaz. Pembuatan bokashi dilakukan secara aerob berdasarkan hasil penelitian Daryono dan Alkas (2017). Secara teknit, pembuatan pupuk bokashi pelepah sawit dimulai dengan mencacah pelepah sawit saja tidak termasuk daun dan lidinya karena akan dimanfaatkan untuk membuat piring ayaman dari lidi sawit. Pelepah dicacah dengan menggunakan mesin pencacah yang telah didesain khusus untuk pelepah. Pencampuran kotoran ternak, dedak, sekam, larutan EM-4 dan molase dilakukan kemudian dan diaduk sampai merata. Setelah itu, penyiraman dilakukan pada adonan bokashi dengan menggunakan gembor. Proses selanjutnya adalah memasukkan karung-karung ke dalam terpal besar kemudian bila bokashi mengalami kering maka dilakukan penyiraman dengan air. Pengadukan dilakukan setiap 3 hari. Analisis kematangan bokashi dilakukan dengan melihat parameter perubahan bau, perubahan warna, $\mathrm{pH}$, kadar air, kelembaban, perubahan temberatur, $\mathrm{C} / \mathrm{N}$ ratio (Nurlianti \& Prihanani, 2018)

\section{HASIL DAN PEMBAHASAN}

\section{Transfer Teknologi Pembuatan Pupuk Bokashi}

Kegiatan dilaksanakan dirumah ketua kelompok dengan peserta sebanyak 10 orang dan ditambah dengan warga lainnya sehingga berjumlah 25 orang. Materi yang diberikan adalah teknis pembuatan pupuk bokashi secara khusus berbahan dasar pelepah sawit dan kotoran ayam ras serta pengetahuan tentang pemanfaatan pupuk bokashi tersebut serta prospek usaha ekonomi produktif di bidang tersebut. Materi tersebut disampaikan oleh Tim Pengabdian Unihaz dengan menggunakan metode komunikasi penyuluhan kelompok partisipatif yaitu lebih banyak melibatkan komunikan dalam menyampaikan materi sehingga terkesan tidak menggurui. Tim pengabdi memfasilitasi partisipasi mitra peserta kegiatan.

Kegiatan pengabdian ini cukup berhasil manarik minat komunikan yang ditunjukkan dengan antusiasme para peserta mengajukan pertanyaan serta mengikuti penjelasan. Penggunaan media infocus sangat membantu untuk menunjukkan gambar serta video sehingga materi yang diterima oleh masyarakat lebih jelas. Pada akhir kegiatan, testemoni dari para pelaku usaha yang telah sukses terlebih dahulu dalam pembuatan bokashi ditayangkan dari berbagai kelompok tani.

Kelemahan dalam kegiatan ini adalah peserta tidak terlalu fokus ke materi secara teknis namun lebih banyak perhatiannya kepada pengetahuan yang lebih bersifat umum sehingga dikhawatirkan prosedur pembuatan bokashi tidak dapat ditangkap secara rinci. Kelemahan metode penyuluhan partisipatif ini membutuhkan waktu yang relatif lebih lama dan pembicaraan dapat menyimpang dari arah pembelajaran yang telah ditetapkan sebelumnya. Tim pengabdian melanjutkan kegiatan dengan metode demonstrasi plot di lapangan sehingga anggota KWT Padang Baru menjadi lebih memahami secara mendalam.

\section{Demonstrasi Plot Pembuatan Pupuk Bokashi}

Kelanjutan penyuluhan dan diskusi mengenai pemanfaatan pelepah daun kelapa sawit dan kotoran ayam ras sebagai bahan dasar pembuatan bokashi adalah demonstrasi plot pembuatan pupuk bokashi. Kegiatan demonstrasi dilakukan dengan bantuan trainer yaitu Kelompok Tani Panorama. Kelompok Tani Panorama adalah kelompok tani yang telah sukses dalam pembuatan bokashi. Kelompok tani ini dihadirkan dengan harapan dapat memberikan motivasi bagi KWT Padang Baru yang baru berdiri untuk lebih bersemangat memajukan KWT Padang Baru. Selain 
itu, kegiatan dihadiri oleh Tim Pengabdian Unihaz dan masyarakat Babatan yang bukan anggota KWT Padang Baru. Demonstrasi ini membuat mitra pengabdian secara nyata melakukan pemrosesan bokashi.

Kegiatan pembuatan bokashi diawali dengan persiapan bahan utama yaitu mencacah pelepah sawit dengan menggunakan copper (Gambar 1). Bila menggunakan tenaga manusia secara manual, mencacah pelepah sawit menjadi ukuran 2-4 cm membutuhkan waktu yang cukup lama. Pengalaman kelompok mitra hanya menghasilkan 2 gunungan dengan bobot $500 \mathrm{~kg}$ selama satu hari. Namun, pencacahan menggunakan mesin pencacah menghasilkan lebih banyak karena menggunakan tenaga mesin. Pada akhir kegiatan, Tim Pengabdian Unihaz menyumbangkan mesin copper penghancur pelepah sawit yang didisain khusus untuk pelepah dengan menggunakan motor sehingga kendala pencacahan dapat di atasi.

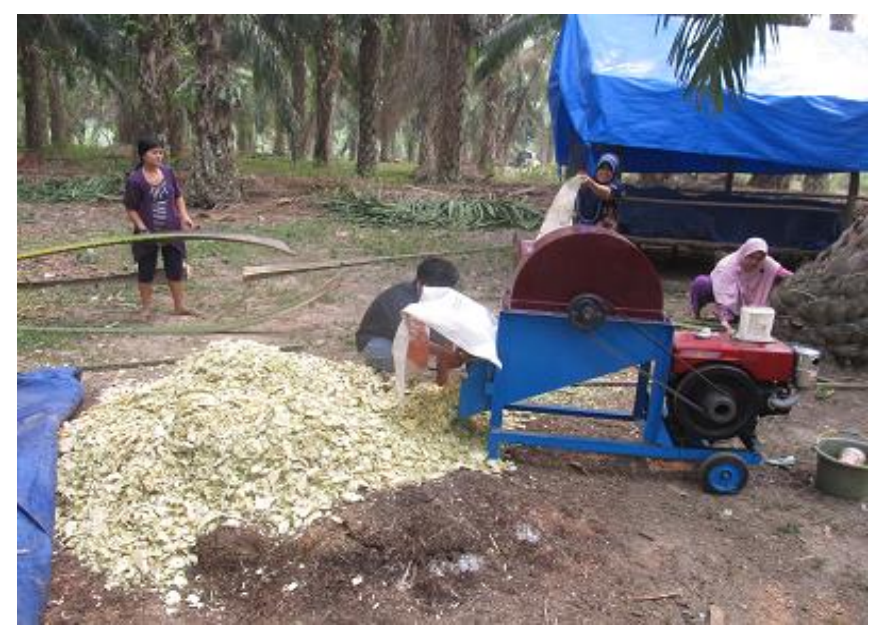

Gambar 1 Pencacahan pelepah sawit dengan mesin copper

Tahap selanjutnya adalah persiapan bahan lainnya yaitu kotoran ayam ras. Semua bahan ditakar sesuai komposisi bahan-bahan untuk bokashi seperti sekam dan dedak (Gambar 2). Bahan kering dan bahan basah (molase dan air) dicampurkan sampai terbentuk adonan yang dapat dikepal. Kandungan air sudah dinyatakan cukup bila adonan dikepal tanpa mengeluarkan air.

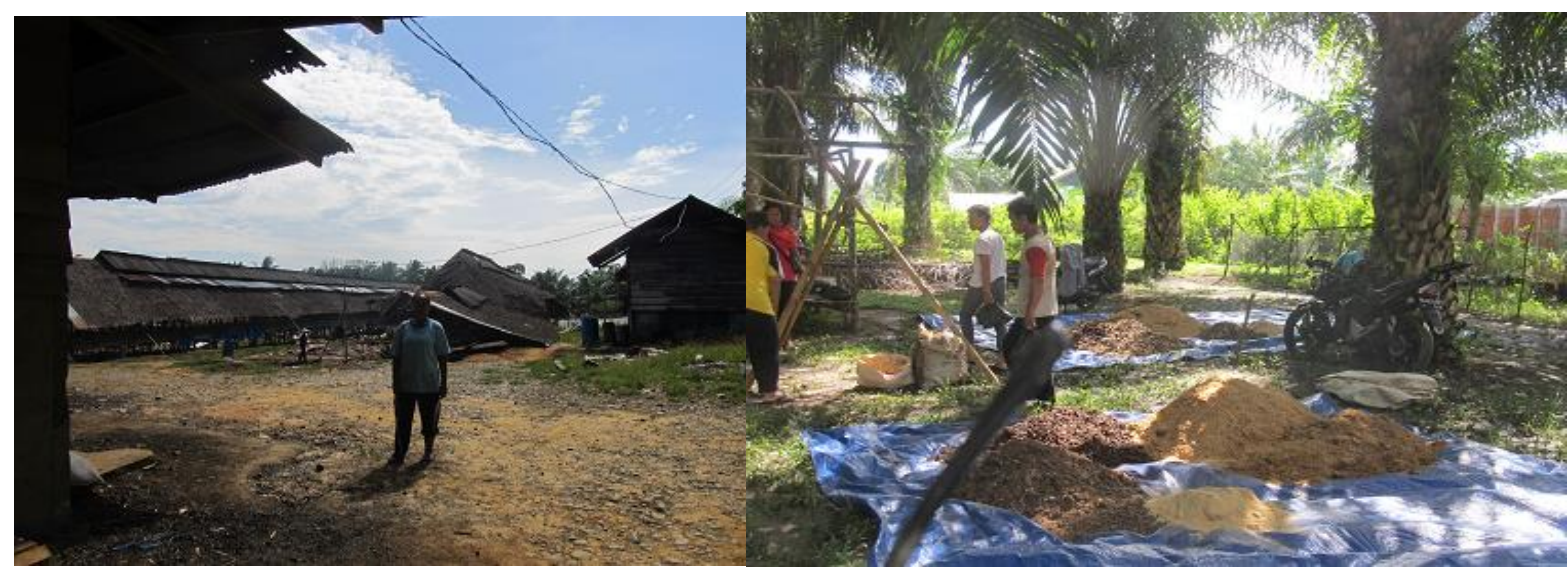

Gambar 2 Pengumpulan limbah ternak ayam ras dan pencampuran bahan

Fermentasi secara aerobik dilakukan di dalam karung-karung dan ditutupi oleh terpal (Gambar 3). Terpal dapat dibuka misalnya pada hari ke-3 untuk pengontrolan suhu. Bila suhu adonan bokashi di atas $50^{\circ} \mathrm{C}$, maka adonan disirami air sehingga suhu menjadi turun (Gambar 4). Pengecekan dan analisis tingkat kematangan bokashi sudah mulai dapat dilakukan pada pada hari ke-7. Bokashi yang telah matang ditandai dengan warna kemerahan dan kehitaman, bau seperti bau tanah sudah tidak ada bau bahan aslinya, $\mathrm{pH}$ netral, temperatur berkisar $30-38^{\circ} \mathrm{C}$ (Daryono \& Alkas, 2017). Fermentasi dilanjutkan jika bokashi belum jadi. Bokashi yang telah matang dikeluarkan dan diayak. Bokashi dikemas dengan karung dengan ukuran karung $20 \mathrm{~kg}$ (Gambar 5). Pupuk bokashi pelepah sawit dan limbah ternak memerlukan waktu fermentasi selama 7-14 hari hingga berwarna hitam dan berbau tanah dan tekstur remah dan unsur hara bokashi yaitu $\mathrm{C}$ organik dan $\mathrm{C} / \mathrm{N}$ ratio yang memenuhi standar organik Peraturan Departemen Pertanian 
No.70/Permetan/SR.140/10/2011 (Daryono \& Alkas, 2017). Hasil penelitian yang dilaporkan oleh Nurlianti dan Prihanani (2015) menunjukkan bahwa pembuatan bokashi berbahan limbah kebun sawit yaitu pelepah dan limbah ternak ayam ras menghasilkan bokashi dengan kandungan hara N 1,66\%; P 0,3\%; K 1,16\%.

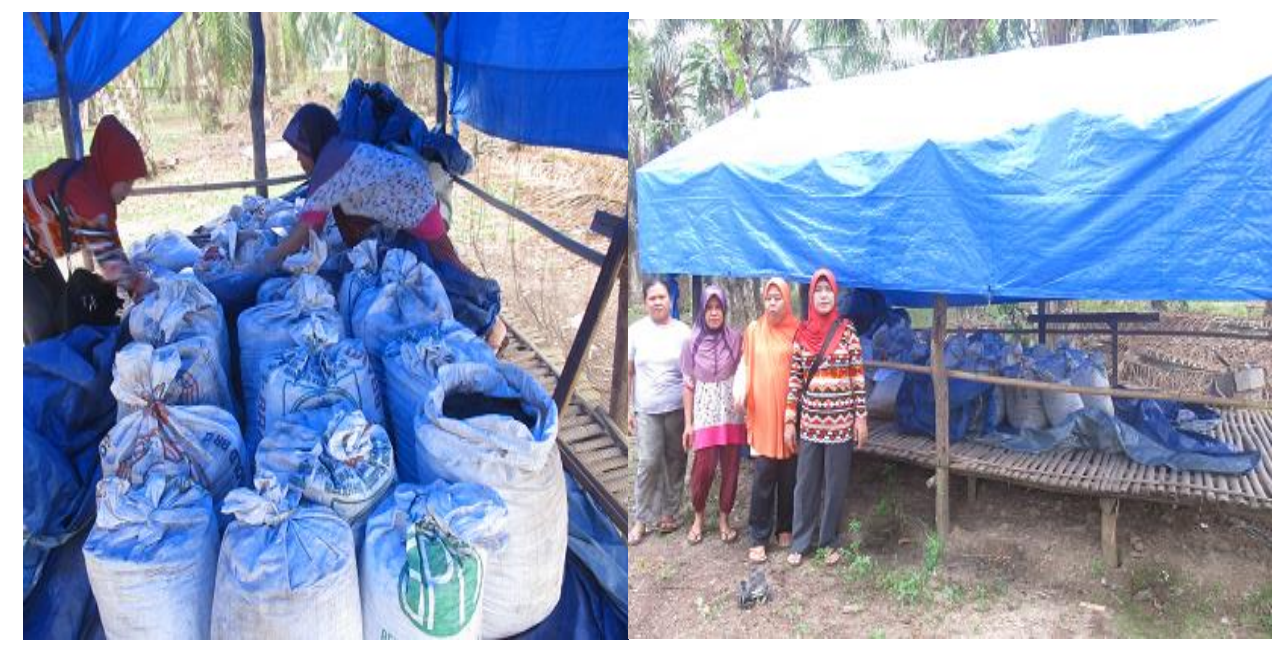

Gambar 3 Proses fermentasi adonan bokashi

Bobot bokashi yang diperoleh setelah difermentasi dengan bahan baku mentah $100 \mathrm{~kg}$ adalah $60 \mathrm{~kg}$. Pembuatan bokashi selanjutnya dilakukan sebanyak 10 kali selama 10 minggu atau setiap minggu oleh kelompok wanita tani secara mandiri dengan pendampingan. Produksi bokashi yang sudah dihasilkan diayak kemudian siap digunakan untuk budidaya pertanian. Hasil yang telah dicapai selama program pengabdian dari bulan Januari hingga Juni 2018 yaitu 40 karung bokashi yang sudah di kemas dan siap untuk dipasarkan (Gambar 5). Setelah ada mesin pencacah (copper), potensi untuk memproduksi pupuk bokashi menjadi lebih tinggi. Kelompok ini telah mampu menghasilkan bokashi yang siap dijual.

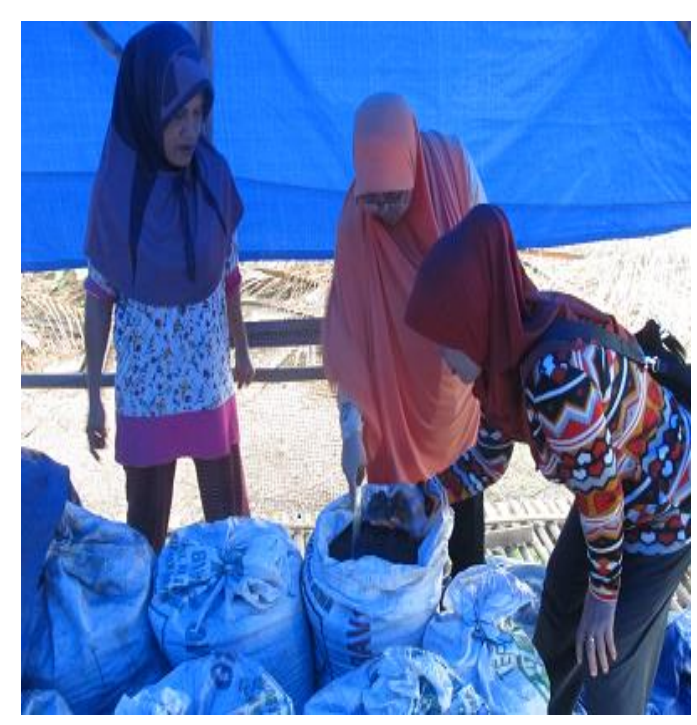

Gambar 4 Pengecekan dan pemeliharaan bokashi

Target dibidang pemasaran pupuk bokashi ini telah dicapai dengan indikator ada beberapa kelompok tani lain yang membutuhkan produk bokashi tersebut untuk usaha tani. Kelompok-kelompok yang membutuhkan bokashi ini adalah kelompok tani penyedia bibit bunga dan produksi sayuran. Kelompok tani tersebut telah datang untuk membeli produk bokashi yang dihasilkan dalam jumlah yang cukup banyak.

Target kegiatan pengabdian dapat dicapai yaitu memberikan keterampilan kepada anggota KWT Padang Baru agar memiliki kegiatan produktif di samping kegiatan utamanya sebagai seorang ibu rumah tangga. Kegiatan produktif yang dimaksud dimulai dengan adanya pemahaman untuk dapat memanfaatkan bahan-bahan alam atau limbah yang ada disekitar kehidupannya tanpa adanya modal berupa finansial yang cukup memberatkan bagi mereka. Setelah 
adanya pemahaman tentang hal tersebut, ide-ide kreatif dari kelompok wanita tani dapat berkembang sendiri untuk melakukan kegiatan produktif dengan melihat peluang-peluang yang ada disekitarnya.

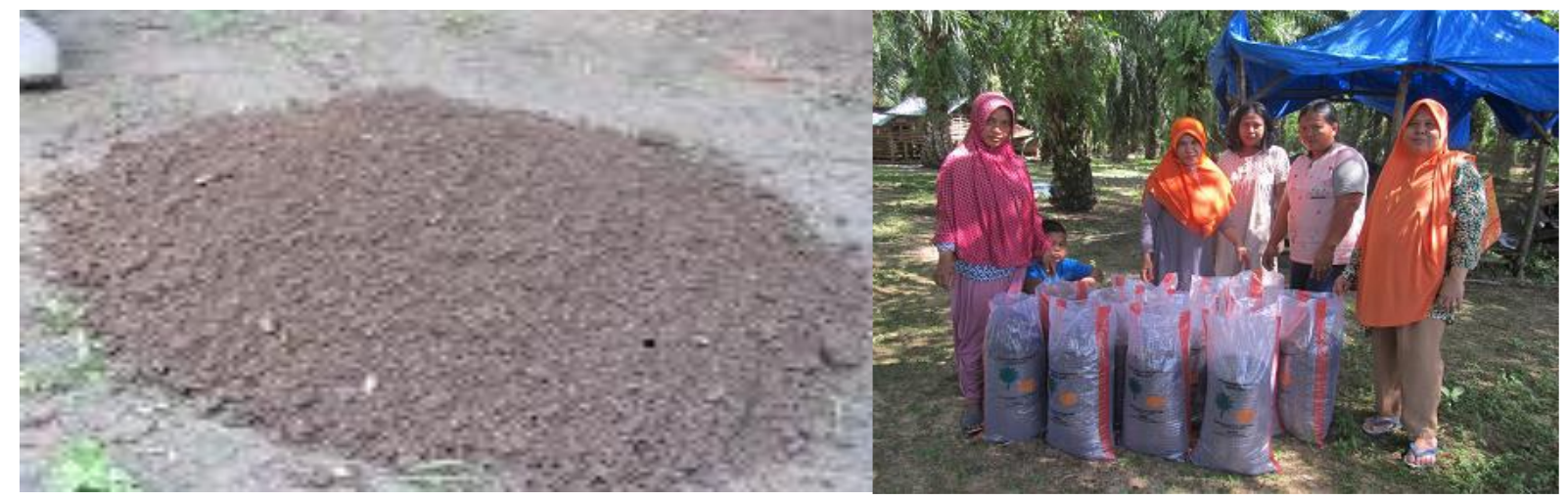

Gambar 5 Produk bokhasi siap dipasarkan

\section{Pendampingan KWT Padang Baru}

Kegiatan pendampingan dilaksanakan sebagai tindak lanjut dari kegiatan pengabdian pada masyarakat. KWT dikunjungi oleh tim pengabdi setiap bulan selama pendampingan untuk mengevaluasi keberlanjutan program pembuatan pupuk bokashi. Selain itu, tujuan pendampingan adalah mencarikan solusi dari masalah yang dihadapi serta bantuan untuk mempromosikan produk yang dihasilkan (Tabel 1).

Tabel 1 Evaluasi kegiatan pengabdian sebelum dan sesudah program pengabdian

\begin{tabular}{llll}
\multirow{2}{*}{ No } & \multicolumn{1}{c}{ Uraian Kegiatan } & \multicolumn{2}{c}{ Program Kegiatan Pengabdian } \\
\cline { 3 - 4 } & & \multicolumn{1}{c}{ Sebelum } & \multicolumn{1}{c}{ Sesudah } \\
\hline 1 & $\begin{array}{l}\text { Pengetahuan tentang } \\
\text { pemanfaatan limbah pertanian }\end{array}$ & $\begin{array}{l}\text { Belum ada pengetahuan } \\
\text { untuk memanfaatkan limbah } \\
\text { pertanian }\end{array}$ & $\begin{array}{l}\text { Telah memiliki pengetahuan } \\
\text { pemanfaatan limbah pertanian }\end{array}$ \\
2 & $\begin{array}{l}\text { Keterampilan pembuatan bokashi } \\
\text { Kegiatan ekonomi produktif bagi } \\
\text { anggota kelompok wanita tani } \\
\text { Memiliki produk bokashi yang } \\
\text { siap di pasarkan }\end{array}$ & Belum ada keterampilan & $\begin{array}{l}\text { Sudah memilik keterampilan } \\
\text { Sudah dimulai }\end{array}$ \\
& & & Sudah memiliki produk \\
\hline
\end{tabular}

\section{KESIMPULAN}

KWT Padang Baru adalah kelompok wanita yang berkeinginan untuk menambah pendapat keluarga dengan usaha membuatan bokashi tandan sawit dengan memanfaatkan bahan baku limbah pertanian disekitar kehidupan mereka. Mereka telah mempu membuat bokashi berbahan dasar tandan sawit dan limbah ternak ayam ras dan siap untuk dipasarkan. Dalam jumlah terbatas telah mampu menjual produknya untuk memenuhi kebutuhan kelompok tani lain atau masyarakat umum yang membutuhkan.

\section{UCAPAN TERIMA KASIH}

Ucapan terimakasih disampaikan pada semua pihak yang telah membantu kegiatan Tim Pengabdian Unihaz dan kepada Direktorat Riset dan Pengabdian Masyarakat, Direktorat Jenderal Penguatan Riset dan Pengembangan Kementerian Riset, Teknologi, dan Pendidikan Tinggi atas pendanaan melalui skim IPTEK bagi Masyarakat tahun pelaksanaan 2018.

\section{DAFTAR PUSTAKA}

BPS Seluma. (2020). Statistika Kabupaten Seluma. https://selumakab.bps.go.id/ diakses 6 Juni 2021.

Daryono, \& Alkas, R. T. (2017). Pembuatan bokashi limbah pelepah dan daun kelapa sawit (Elaeis Guineensis Jacq.) Buletin Loupe, 14(02), 6-12. 
Fitriany, E. A. \& Abidin, Z. (2020). Pengaruh pupuk bokashi terhadap pertumbuhan mentimun (Cucumis sativus L.) di Desa Sukawening, Kabupaten Bogor, Jawa Barat. Jurnal Pusat Inovasi Masyarakat, 2(5), 881-886.

BPTP Kalimantan Tengah. (2015). Membuat Kompos dengan Aktivator EM4. http://kalteng.litbang.pertanian.go.id/ind/index.php/publikasi-mainmenu-47-47/teknologi/532-membuatkompos-dengan-aktivator-em424 diakses 30 Mei 2021.

Firmansyah, A. M. (2010). Pelatihan petani plasma kelapa sawit. Balai Pengkajian Teknologi Pertanian Kalimantan Tengah

Gunawan, \& Talib, C. (2014). Potensi pengembangan bioindustri dalam sistem integrasi sapi sawit. Wartazoa, 24(2), 167-74.

Kaya, E. 2013. Pengaruh kompos jerami dan pupuk npk terhadap n-tersedia tanah, serapan-n, pertumbuhan, dan hasil padi sawah (Oryza sativa L.). Agrologia, 2(1), 43- 50.

Nurlianti, \& Prihanani. (2015). Respon pertumbuhan jahe pada berbagai tegakan sawit dengan aplikasi bokhasi limbah pertanian plus sebagai substitusi pupuk pada teknologi leisa. Laporan Akhir Hibah Bersaing Tahun Ke-1. Lembaga Penelitian dan Pengabdian pada Masyarakat Universitas Prof. Dr. Hazairin, SH.

Nurlianti, \& Prihanani. (2018). Peran decompeser dalam pembuatan kompos dari limbah padi dan limbah sawit. Jurnal Agroqua, 16(1), 32-41.

Syahfitri, M. M. (2008). Analisa unsur hara fosfor $(P)$ pada daun kelapa sawit secara spektrofotometri di pusat penelitian kelapa sawit (PPKS) Medan. Universitas Sumatera Utara. Karya Ilmiah. Tidak dipublikasikan.

Siboro, E. S., Surya, E., Herlina, N. (2013). Pembuatan pupuk cair dan biogas dari campuran limbah sayuran. Jurnal Teknik Kimia USU, 2(3), 40-43. 